\title{
Extreme change in sulfide concentrations in the Black Sea during the Little Ice Age reconstructed using molybdenum isotopes
}

\author{
G.L. Arnold ${ }^{1 *}$, T.W. Lyons², G.W. Gordon ${ }^{3}$, and A.D. Anbar ${ }^{3,4}$ \\ ${ }^{1}$ Max Planck Institute for Marine Microbiology, 28359 Bremen, Germany \\ 2Department of Earth Sciences, University of California, Riverside, California 92521-0423, USA \\ ${ }^{3}$ School of Earth and Space Exploration, Arizona State University, Tempe, Arizona 85287-1404, USA \\ ${ }^{4}$ Department of Chemistry and Biochemistry, Arizona State University, Tempe, Arizona 85287-1404, USA
}

\section{ABSTRACT}

The Black Sea is the largest and most studied anoxic basin in the modern world. Much of this research has focused on the redox structure of the water column, specifically on the driving forces behind variations in the position, stability, and structure of the oxic-anoxic interface (chemocline). However, none of these studies has been able to quantify the historical sulfide concentrations associated with the changes in chemocline depth. Using the isotopic composition of molybdenum in sediments as a proxy, we show for the first time that varying concentrations of dissolved sulfide can be fingerprinted in historical systems. Our molybdenum isotope data indicate that in the region of the Bosporus inlet, the chemocline rose more than $65 \mathrm{~m}$, reaching concentrations over $100 \mu \mathrm{M}$ sulfide in the bottom water ca. $300 \mathrm{yr}$ B.P. This historical shoaling of the chemocline and extreme change in bottom-water sulfide concentration exceeds the modern changes that have been observed directly and attributed to anthropogenic influences on the Black Sea chemistry/hydrology. The first cold interval of the Little Ice Age, when temperature and circulation changes occurred in the Black Sea basins, may have provided the natural trigger for this extreme rise in bottom-water sulfide concentrations.

\section{INTRODUCTION}

The sulfide interface in the modern Black Sea is located at a depth of $\sim 80 \mathrm{~m}$ in the central western basin, and deepens to $130 \mathrm{~m}$ along the basin margin in the area of the Bosporus inlet (Lyons et al., 1993; Repeta, 1993; Manske et al., 2005). Several lines of geochemical evidence, including sedimentary sulfur, iron, and manganese concentrations, as well as organic biomarkers, suggest that the depth of the sulfide interface in the Black Sea has varied in the past and that sediments deposited on the presently oxic shelf in the area of the Bosporus inlet were covered by sulfidic bottom waters for a period of time during the past 300 yr (Lyons et al., 1993; Repeta, 1993; Damsté et al., 1993; Lyons and Severmann, 2006; Severmann et al., 2008). Although these geochemical proxies yield information about the presence or absence of sulfidic bottom waters in the past, they are unable to quantify the concentration of sulfide at any point in time. Such quantification is essential to characterizing the magnitude of natural perturbations as a baseline against which potential anthropogenic impact can be assessed.

The molybdenum (Mo) isotope system can provide quantitative information on historical trends in bottom-water sulfide concentrations. Molybdenum isotope data $\left(\delta^{98} \mathrm{Mo}\right.$; see the GSA Data Repository ${ }^{1}$ ) have previously been used

*E-mail: gail.1.arnold@gmail.com.

${ }^{1}$ GSA Data Repository item 2012179, description of methods, historical sulfide calculations, supporting figures, and data table, is available online at www.geosociety.org/pubs/ft2012.htm, or on request from editing@geosociety.org or Documents Secretary, GSA, P.O. Box 9140, Boulder, CO 80301, USA. as a proxy for the global distribution of anoxic conditions in ancient oceans (e.g., Barling et al., 2001; Siebert et al., 2003; Arnold et al., 2004; Wille et al., 2007; Pearce et al., 2008) but are sensitive to local redox conditions, requiring high and persistent sulfide concentrations in bottom waters for effective use of the global proxy (Gordon et al., 2009; Dahl et al., 2010). Due to this sensitivity, the $\delta^{98} \mathrm{Mo}$ of sediments may reflect not only the presence/absence of sulfide but also its concentration. This relationship between the $\delta^{98} \mathrm{Mo}$ of modern sediments and bottom-water concentrations of dissolved sul-
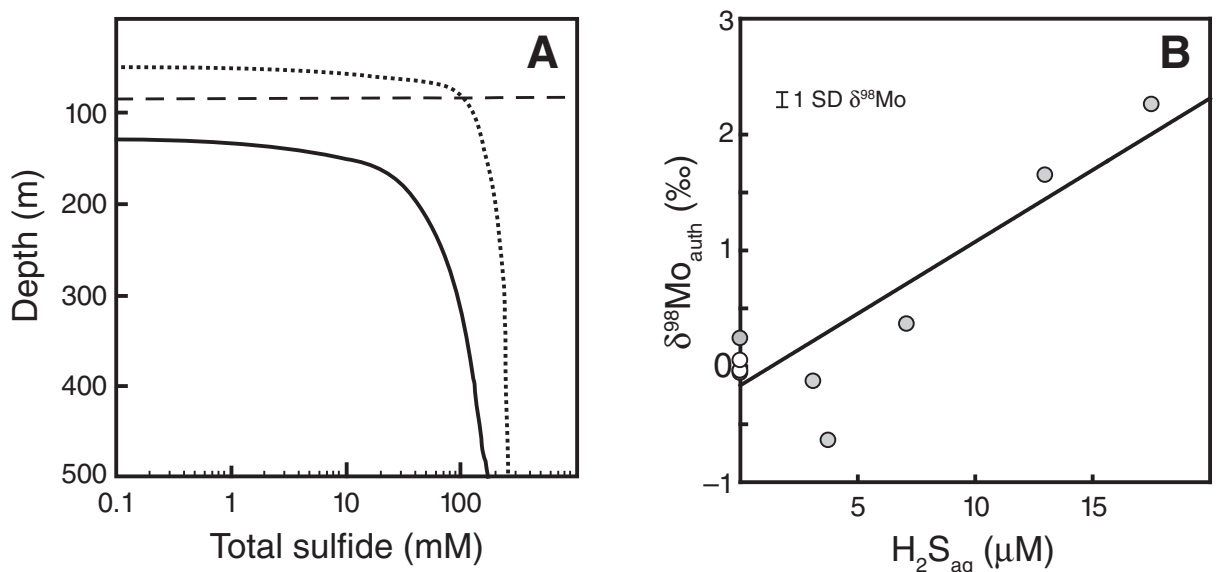

Figure 1. A: Total sulfide concentration with depth in the water column of the Black Sea (after Neretin et al., 2001). Solid and dotted lines represent the sulfide concentration profile today and at ca. $300 \mathrm{yr}$ B.P., respectively. B: $\delta^{98} \mathrm{Mo}_{\text {uth }}$ in surface sediments versus concentration of $\mathrm{H}_{2} \mathrm{~S}_{\mathrm{aq}}$ in overlying bottom waters. Open circles ( $\delta^{98}$ Mo for oxic sites, this study) and filled circles (data from Neubert et al., 2008) establish a linear relationship: $\delta^{98} \mathrm{Mo}_{\text {ath }} \pm 0.08=(0.1239$ $\pm 0.0214)\left[\mathrm{H}_{2} \mathrm{~S}_{\mathrm{aq}}\right]-(0.1653 \pm 0.1515), \mathrm{R}^{2}=0.79$; all errors are one standard deviation (1 SD). 
records the bottom-water sulfide concentration at the time of deposition, a $\delta^{98} \mathrm{Mo}$ profile for a sediment column can reveal historical variation in bottom-water sulfide concentrations for that site. If the relationship of Neubert et al. (2008) is representative of conditions expressed more broadly in the Black Sea over both space and time, sedimentary $\delta^{98}$ Mo can be used to track the historical changes in bottom-water sulfide concentration, something that has so far escaped quantification.

\section{SAMPLES AND METHODS}

We analyzed the Mo isotope composition $\left(\delta^{98} \mathrm{Mo}\right)$ of sediments from multiple stations in the Black Sea. Stations 3 and 4 (Lyons et al., 1993) are located on the presently oxic western shelf near the inlet of the Bosporus at water depths of 85 and $115 \mathrm{~m}$, respectively. Stations 16 and 17 are located in the oxic region of the Bay of Sinop. We measured the $\delta^{98} \mathrm{Mo}$ at various depths in the surface sediment at all four stations. Stations 3 and 4 are of particular interest because both have been identified by other geochemical proxies to record past periods of euxinic bottom waters (Lyons et al., 1993; Lyons and Severmann, 2006; Severmann et al., 2008). The water column at these stations is presently oxic, with undetectable sulfide in the sediment pore water. Cesium isotope and ${ }^{210} \mathrm{~Pb}$ data from station 3 indicate that these sediments have experienced only minimal homogenization that perhaps broadened but did not obliterate the high-resolution chemostratigraphy (Lyons, 1991; Lyons et al., 1993). We specifically generated $\delta^{98} \mathrm{Mo}$ profiles from these stations over the upper $\sim 18 \mathrm{~cm}$ with the goal of reconstructing past chemocline properties and variability over the past $\sim 300$ yr (Fig. 2; Table DR1 in the Data Repository). Stations 16 and 17 were used to establish a lithogenic baseline for Mo concentration and $\delta^{98} \mathrm{Mo}$ representative of persistently oxic shelf sediments.

Molybdenum and other elemental concentrations were measured by inductively coupled plasma-mass spectrometry (ICP-MS), either using a multielement external standard solution combined with internal standards to monitor drift in instrument sensitivity or using isotope dilution with a calibrated ${ }^{97} \mathrm{Mo}$ spike solution. Molybdenum isotope compositions were determined by multiple-collector ICPMS (Thermo Neptune ${ }^{\circledR}$ ) following the analytical procedure outlined by Gordon et al. (2009) (see the Data Repository).

\section{FIDELITY OF THE MO ISOTOPE PROXY}

The use of the Mo isotope signature of sediments as a paleoproxy for bottom-water chemistry is not always straightforward. Debate exists, for example, as to whether the Mo isotope signature might reflect pore-water chemistry

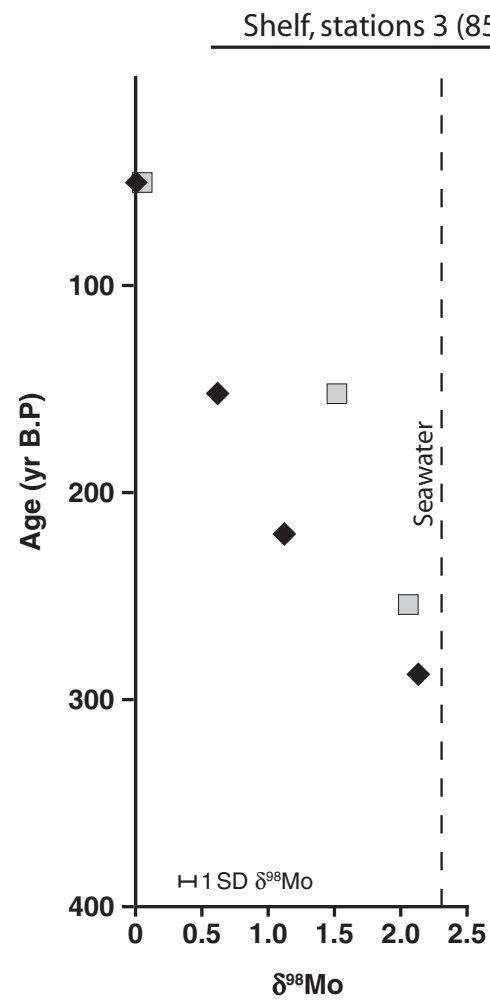

(\%०)

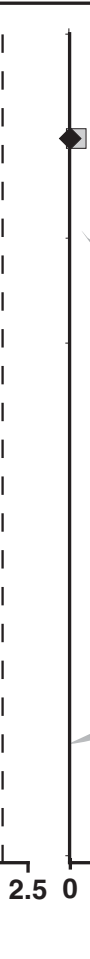

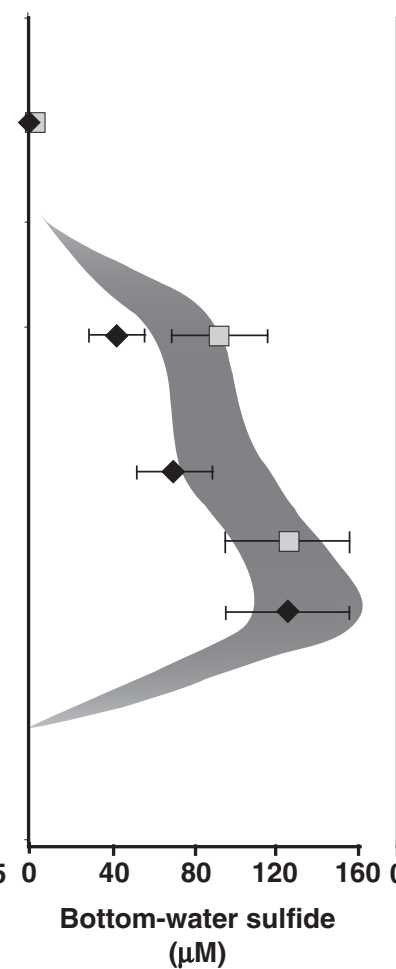

$(\mu \mathrm{M})$

Figure 2. Mo isotope compositions of sediments and calculated bottom-water sulfide concentrations (station 3, filled diamonds; station 4, filled squares) and isorenieratene (after Repeta, 1993, his box core 3). Due to low Mo concentrations, the Mo isotope composition for samples older than $100 \mathrm{yr}$ B.P. was corrected for the detrital Mo contribution (Table DR1 [see footnote 1]). Sediment ages for stations 3 and 4 were determined from an average sedimentation rate of $0.059 \mathrm{~cm} \mathrm{yr}^{-1}$ based on an extrapolation of ${ }^{210} \mathrm{~Pb}$ relationships (Lyons et al., 1993). The start and end of sulfidic bottom waters at station 3 is constrained by the appearance of isorenieratene in the deep basin and the return to oxic sedimentary $M n_{\mathrm{T}} / \mathrm{Al}$ values at station 3 , respectively (Fig. DR1; Table DR3; Lyons and Severmann, 2006). The shaded area in the central plot illustrates the rapid rise, followed by gradual retreat, of the sulfide interface.

instead. Although there have been no studies directly addressing this question, the combined sulfide and Mo data available from a site on the Romanian shelf break in the Black Sea may provide insight. During a cruise of the R/V Petr Kottso in September 1997, an 5 m long core was retrieved from a site on the Romanian shelf break (station 6; Nägler et al., 2005; Jørgensen et al., 2004). At the time of core retrieval, the concentration of total dissolved sulfide in the bottom water was $75 \mu \mathrm{M}$, and an increase from a value of $110 \mu \mathrm{M}\left(\sim 24 \mu \mathrm{M} \mathrm{H}_{2} \mathrm{~S}_{\mathrm{aq}}\right)$ just below the sediment-water interface to nearly $400 \mu \mathrm{M}$ $\left(\sim 89 \mathrm{MM} \mathrm{H}_{2} \mathrm{~S}_{\mathrm{aq}}\right)$ was observed through the Unit I sediments (Jørgensen et al., 2004). Nägler et al. (2005) measured the Mo isotope composition of the sediment at nine depths over $\sim 5 \mathrm{~m}$ of core. Unfortunately, in the study of Nägler et al. (2005), no samples were analyzed in the time windows 500-350 yr B.P. or 350-250 yr B.P., where we would expect to observe the maximum regression and shoaling of the chemocline, respectively. Therefore, we cannot validate a shoaling of the chemocline in the study area of Nägler et al. (2005) contemporaneous with what we describe from the area of the Bosporus inlet. However, and importantly, in view of the sulfide switch point required to preserve the heaviest Mo isotope composition ( $11 \mu \mathrm{M} \mathrm{H}_{2} \mathrm{~S}_{\mathrm{aq}}$; Erickson and Helz, 2000), the pore-water sulfide concentrations were well above that critical value. Hence, the sediments were also exposed to pore-water sulfide concentrations well above the proposed switch point.

If Mo enrichment and the isotopic composition are dominated by pore-water chemistry, the sediments analyzed by Nägler et al. (2005) should reflect heavy Mo isotope compositions, as observed in the surface sediments in the deep basin today-i.e., $\delta^{98} \mathrm{Mo}=+2.36 \%$ $\pm 0.09 \%$ o (one standard deviation [1 SD]) (Table DR2)where bottom-water sulfide concentrations are similar. Instead, the Mo isotope composition of the Unit I sediments reported by Nägler et al. (2005) is in all cases lighter than this by $0.5 \%$ o $-0.8 \%$ o $\left(\delta^{98} \mathrm{Mo}\right)$, suggesting that bottomwater chemistry and Mo enrichment at or above the sediment-water interface at the time of deposition are the primary controls. By analogy, we can regard $\delta^{98} \mathrm{Mo}$ in our sediments as 
representative of bottom-water conditions at the time of deposition.

\section{RESULTS AND DISCUSSION}

For the sediments of the persistently oxic shelf, the average concentration of sedimentary molybdenum, [Mo], is $\sim 0.7 \mathrm{ppm}$, with a $\delta^{98} \mathrm{Mo}$ of $-0.07 \%$ $\pm 0.08 \%$ ( 1 SD) (Table DR 1$)$. These values fall exactly within expectations for sediments with little to no authigenic Mo enrichment-i.e., average crust-indicating that the Mo in these sediments derives entirely from lithogenic sources.

At stations 3 and 4, we observe a decrease in $\delta^{98} \mathrm{Mo}_{\text {auth }}$ with shallowing sediment depth from $+2.1 \%$ o to $-0.04 \%$ ond $+2.1 \%$ o to $+0.05 \%$ o, respectively (Fig. 2; Table DR1; Fig. DR1). We infer that the up-core shifts in $\delta^{98} \mathrm{Mo}$ reflect the progression from higher bottom-water sulfide concentrations in the past to the present-day oxic conditions at these sites. Cesium isotope and ${ }^{210} \mathrm{~Pb}$ chronometers constrain this transition to the past $300 \mathrm{yr}$ (Lyons et al., 1993).

Applying the linear relationship presented by Neubert et al. (2008) to our data, the bottomwater $\left[\mathrm{H}_{2} \mathrm{~S}_{\mathrm{aq}}\right]$ was $\sim 18 \mu \mathrm{M}\left(\left[\Sigma \mathrm{H}_{2} \mathrm{~S}\right] \approx 126 \mu \mathrm{M}\right)$ between 250 and $300 \mathrm{yr}$ B.P. at shelf depths in the area of the Bosporus inlet (Table 1; Fig. 2). A steady up-core decrease from the deep heavy $\delta^{98}$ Mo toward values typical of detrital sediment lacking Mo enrichment implies that the chemocline returned slowly and continuously over an 200 yr period to a deeper position, consistent with a progressive decrease in sulfide concentration. Biomarker data from a deepwater site indicate that the chemocline did not retreat entirely. It remains within the euphotic zone in the central basin today (Repeta, 1993). However, due to the convex nature of the chemocline, its retreat on the basin margin extended to greater depths, leading ultimately back to the oxic conditions now seen at stations 3 and 4 (Table 1; Figs. 1A and 3).

Unfortunately, the paucity of older sediment samples from our sites prevents us from fully reconstructing fluctuations in bottom-water sul- fide concentrations on the shelf prior to $300 \mathrm{yr}$ B.P. However, complementary information can be gained from sediments at a deepwater site $\sim 120 \mathrm{~km}$ to the northeast in the central western basin where isorenieratene, an organic biomarker indicative of $\mathrm{H}_{2} \mathrm{~S}$ in the photic zone, is absent between 500 and 350 yr B.P. (Repeta, 1993) (Fig. 2). From the biomarker data of Repeta (1993), we infer that from 500 to $350 \mathrm{yr}$ B.P., the sulfide interface in the central western basin was below the photic zone ( 100 m; Manske et al., 2005), which would place the chemocline almost $20 \mathrm{~m}$ below its current depth at $\sim 80 \mathrm{~m}$ at this location. Similarly, the chemocline along the basin margin would have been deeper than the modern depth ( 130 m; Lyons et al., 1993), yielding a minimum depth of $\sim 150 \mathrm{~m}$ in the area of stations 3 and 4, prior to $350 \mathrm{yr}$ B.P. (Fig. 3). The close association between biomarker evidence for sulfide in the photic zone, indicating a shoaling in the chemocline starting ca. 350 yr B.P. (Repeta, 1993), and our heavy $\delta^{98} \mathrm{Mo}_{\text {auth }}$ ca. $300 \mathrm{yr}$ B.P. indicates that not only did the chemocline rise and bottom-water sulfide appear at stations 3 and 4 during this time, but this excursion happened quickly. Specifically, the chemocline rose more than $65 \mathrm{~m}$ in less than $50 \mathrm{yr}$, thus capturing the heaviest Mo isotope composition-consistent with the high sulfide concentrations seen in deep waters today (Fig. 2). This $>65 \mathrm{~m}$ change in the depth of the chemocline exceeds the up to $30 \mathrm{~m}$ of change that has been observed directly during the last 30 to $40 \mathrm{yr}$ and attributed to anthropogenic influences on Black Sea chemistry/hydrology (Murray et al., 1989, 1995; Konovalov et al., 2001; Konovalov and Murray, 2001).

The shoaling of the chemocline is not recorded in the margin sediments at stations 16 and 17 in the eastern basin (Table DR1). An explanation for this difference could be that the chemocline in this region today is at a depth of $\sim 175 \mathrm{~m}$, deeper than what is observed in the area of the Bosporus inlet. If the shoaling event in this region behaved as it did in the Bosporus,
TABLE 1. CALCULATION OF HISTORICAL BOTTOM-WATER SULFIDE CONCENTRATIONS

\begin{tabular}{|c|c|c|c|c|c|c|c|}
\hline & $\begin{array}{c}\text { Age } \\
\text { (yr B.P.) }\end{array}$ & $\begin{array}{c}\delta^{98} \mathrm{Mo}_{\text {auth }} \\
(\%)\end{array}$ & $\begin{array}{c}1 \text { SD } \\
(\% \circ)\end{array}$ & $\begin{array}{c}{\left[\mathrm{H}_{2} \mathrm{~S}_{\mathrm{aq}}\right]} \\
(\mu \mathrm{M})^{\star}\end{array}$ & $\begin{array}{l}1 \mathrm{SD} \\
(\mu \mathrm{M})\end{array}$ & $\begin{array}{c}\text { Total sulfide } \\
(\mu \mathrm{M})^{\S}\end{array}$ & $\begin{array}{l}1 \mathrm{SD} \\
(\mu \mathrm{M})\end{array}$ \\
\hline \multicolumn{8}{|c|}{ Station 3 (85 m) } \\
\hline $8-10 \mathrm{~cm}$ & 153 & 0.62 & 0.08 & 6 & 2 & 44 & 14 \\
\hline $12-14 \mathrm{~cm}$ & 220 & 1.13 & 0.08 & 10 & 3 & 72 & 19 \\
\hline $16-18 \mathrm{~cm}$ & 288 & 2.13 & 0.08 & 19 & 3 & 127 & 31 \\
\hline \multicolumn{8}{|c|}{ Station 4 (115 m) } \\
\hline $8-10 \mathrm{~cm}$ & 153 & 1.51 & 0.08 & 14 & 3 & 93 & 24 \\
\hline $14-16 \mathrm{~cm}$ & 254 & 2.05 & 0.08 & 18 & 3 & 123 & 30 \\
\hline \multicolumn{8}{|c|}{$\begin{array}{l}\text { *Using our data for } \delta^{98} \mathrm{Mo}_{\text {auth }} \text { and the equation for the linear relationship defined in Figure 1, we } \\
\text { calculate the historical }\left[\mathrm{H}_{2} \mathrm{~S}_{\text {aq }}\right] \text { for each time point at stations } 3 \text { and } 4 \text {. } \\
\text { \&In order to estimate total sulfide, we use } \mathrm{pH} \text { values representative of the potential span of conditions } \\
\text { that stations } 3 \text { and } 4 \text { may have experienced (pH data from Goyet et al., 1991). We can then estimate } \\
\text { the historical total sulfide concentrations, following Almgren et al. (1976) and Millero et al. (1988). See } \\
\text { the Data Repository (see text footnote 1) for details of historical }\left[\mathrm{H}_{2} \mathrm{~S}_{\mathrm{aq}}\right] \text { and total sulfide calculations. } \\
\text { SD-standard deviation. }\end{array}$} \\
\hline
\end{tabular}

then a $45 \mathrm{~m}$ rise in the chemocline above the modern level (65 $\mathrm{m}$ above the inferred ancient level) would barely bring the sulfide interface to the depth of station $16(129 \mathrm{~m})$ and would not reach station 17 at $97 \mathrm{~m}$. Regional variations in chemocline structure and behavior make it likely that the rise and fall of the chemocline starting ca. 350 yr B.P. would not have been recorded in the sediments at stations 16 and 17.

\section{IMPLICATIONS}

The rapid shoaling of the chemocline in the Black Sea between 350 and 300 yr B.P.
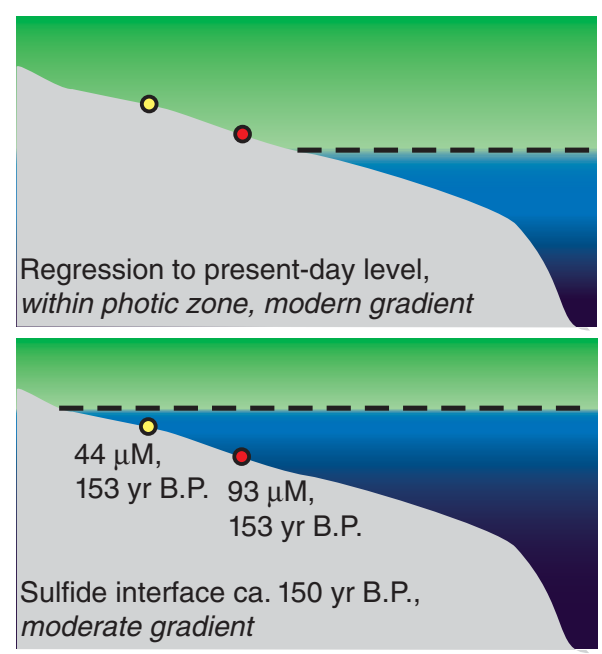

\section{moderate gradient}
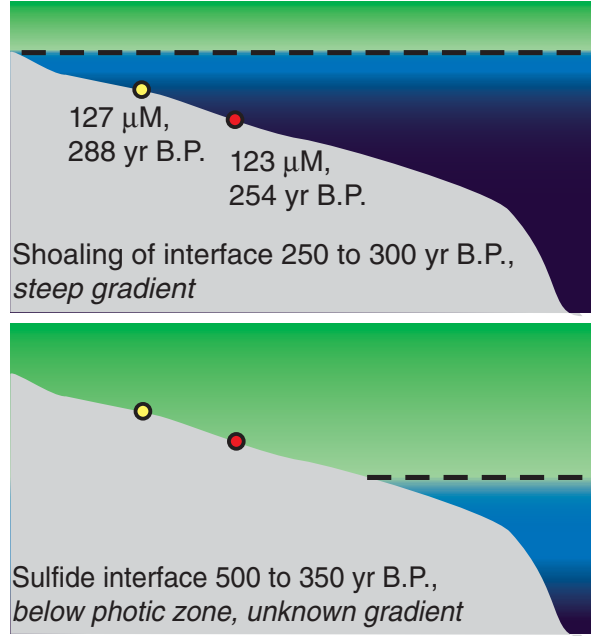

below photic zone, unknown gradient

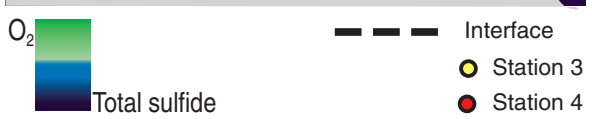

Sketch, not to scale.

Figure 3. Hypothesized changes in the position of the chemocline from $>350 \mathrm{yr}$ B.P. to present. We illustrate that not only has the sulfide interface changed in absolute depth, but the sulfide gradient also steepened. Change in color saturation is representative of the concentration gradients; i.e., darker blue indicates higher total sulfide concentrations (note that the convex structure of the chemocline is neglected because we are depicting the fluctuations as recorded on the basin margin). 
corresponds with the end of the "Peak Bloom Period" of Emiliana huxleyi (Hay et al., 1991), coincident with the first cold interval of the Little Ice Age. Hay et al. (1991) suggested that cold temperatures were responsible for the bloom in E. huxleyi, as potentially facilitated by winter storms that mixed the surface water column and brought nutrient-rich deep water to the surface. The subsequently increased export of organic matter into anaerobic waters may have triggered increased production of hydrogen sulfide by bacterial sulfate reduction. Furthermore, shoaling and steepening/compression of the chemocline may have resulted in a positive feedback, because a smaller portion of the water column was available for aerobic degradation of organic matter, resulting in higher rates of sulfate reduction. This scenario may explain the rapid shift to a shallow chemocline, followed by a more gradual return to deeper chemocline levels in this area.

Here, for the first time, we use the Mo isotope paleoredox proxy in a new way to quantify historical trends in bottom-water sulfide concentrations and the specifics of chemocline dynamics, paving the way for a more detailed basin-wide reconstruction of chemocline fluctuations. Such quantifications and reconstructions have otherwise been elusive. This new application, which exploits the known sensitivity of the Mo isotope system to sulfide concentration, has the potential to yield new insight into the geochemical evolution of the Black Sea and other modern euxinic basins, and may also prove useful in the interpretation of the paleosulfide evolution of ancient anoxic basins throughout Earth history.

\section{ACKNOWLEDGMENTS}

We thank G. Ravizza for providing Black Sea sediment samples from the deep basins. The Mo isotope measurements were made at the W.M. Keck Foundation Laboratory for Environmental Biogeochemistry at Arizona State University. Funding was provided to Anbar and Lyons by the NASA Exobiology Program and the Geobiology and Low-Temperature Geochemistry Program of the National Science Foundation Division of Earth Sciences.

\section{REFERENCES CITED}

Almgren, T., Dyrssen, D., Elgquist, B., and Johansson, O., 1976, Dissociation of hydrogen sulphide in seawater and comparison of $\mathrm{pH}$ scales: Marine Chemistry, v. 4, p. 289-297, doi:10.1016/0304-4203(76)90014-1.

Arnold, G.L., Anbar, A.D., Barling, J., and Lyons, T.W., 2004, Molybdenum isotope evidence for widespread anoxia in mid-Proterozoic oceans: Science, v. 304, p. 87-90, doi:10.1126/science .1091785 .

Barling, J., Arnold, G.L., and Anbar, A.D., 2001, Natural mass-dependent variations in the isotopic composition of molybdenum: Earth and Planetary Science Letters, v. 193, p. 447-457, doi:10.1016/S0012-821X(01)00514-3.

Dahl, T.W., Anbar, A.D., Gordon, G.W., Rosing, M.T., Frei, R., and Canfield, D.E., 2010, The behavior of molybdenum and its isotopes across the chemocline and in the sediments of sulfidic Lake Cadagno, Switzerland: Geochimica et Cosmochimica Acta, v. 74, p. 144-163, doi:10.1016 /j.gca.2009.09.018.

Damsté, J.S.S., Wakeham, S.G., Kohnen, M.E.L., Hayes, J.M., and Deleeuw, J.W., 1993, A 6,000year sedimentary molecular record of chemocline excursions in the Black Sea: Nature, v. 362 , p. $827-829$, doi:10.1038/362827a0.

Erickson, B.E., and Helz, G.R., 2000, Molybdenum(VI) speciation in sulfidic waters: Stability and lability of thiomolybdates: Geochimica et Cosmochimica Acta, v. 64, p. 1149-1158, doi:10.1016/S0016-7037(99)00423-8.

Gordon, G.W., Lyons, T.W., Arnold, G.L., Roe, J., Sageman, B.B., and Anbar, A.D., 2009, When do black shales tell molybdenum isotope tales?: Geology, v. 37, p. 535-538, doi:10.1130 /G25186A.1.

Goyet, C., Bradshaw, A.L., and Brewer, P.G., 1991, The carbonate system in the Black Sea: DeepSea Research Part A. Oceanographic Research Papers, v. 38, Supplement 2, p. S1049-S1068, doi:10.1016/S0198-0149(10)80023-8.

Hay, B.J., Arthur, M.A., Dean, W.E., Neff, E.D., and Honjo, S., 1991, Sediment deposition in the Late Holocene abyssal Black Sea with climatic and chronological implications: DeepSea Research Part A. Oceanographic Research Papers, v. 38, Supplement 2, p. S1211-S1235, doi:10.1016/S0198-0149(10)80031-7.

Jørgensen, B.B., Böttcher, M.E., Luschen, H., Neretin, L.N., and Volkov, I.I., 2004, Anaerobic methane oxidation and a deep $\mathrm{H}_{2} \mathrm{~S}$ sink generate isotopically heavy sulfides in Black Sea sediments: Geochimica et Cosmochimica Acta, v. 68, p. 2095-2118, doi:10.1016/j.gca.2003.07.017.

Konovalov, S.K., and Murray, J.W., 2001, Variations in the chemistry of the Black Sea on a time scale of decades (1960-1995): Journal of Marine Systems, v. 31, p. 217-243, doi:10.1016 /S0924-7963(01)00054-9.

Konovalov, S.K., Ivanov, L.I., and Samodurov, A.S., 2001, Fluxes and budget of sulphide and ammonia in the Black Sea anoxic layer: Journal of Marine Systems, v. 31, p. 203-216, doi:10.1016/S0924-7963(01)00053-7.

Lyons, T.W., 1991, Upper Holocene sediments of the Black Sea: Summary of Leg 4 box cores (1988 Black Sea oceanographic expedition), in Izdar, E., and Murray, J.W., eds., Black Sea oceanography: NATO Science Series, v. 351, p. 401-441.

Lyons, T.W., and Severmann, S., 2006, A critical look at iron paleoredox proxies: New insights from modern euxinic marine basins: Geochimica et Cosmochimica Acta, v. 70, p. 56985722, doi:10.1016/j.gca.2006.08.021

Lyons, T.W., Berner, R.A., and Anderson, R.F., 1993, Evidence for large pre-industrial perturbations of the Black Sea chemocline: Nature, v. 365, p. 538-540, doi:10.1038/365538a0.

Manske, A.K., Glaeser, J., Kuypers, M.M.M., and Overmann, J., 2005, Physiology and phylogeny of green sulfur bacteria forming a monospecific phototrophic assemblage at a depth of 100 meters in the Black Sea: Applied and Environmental Microbiology, v. 71, p. 8049-8060, doi:10.1128/AEM.71.12.8049-8060.2005.

Millero, F.J., Plese, T., and Fernandez, M., 1988, The dissociation of hydrogen sulfide in seawater: Limnology and Oceanography, v. 33, p. 269 274, doi:10.4319/lo.1988.33.2.0269.
Murray, J.W., Jannasch, H.W., Honjo, S., Anderson, R.F., Reeburgh, W.S., Top, Z., Friederich, G.E., Codispoti, L.A., and Izdar, E., 1989, Unexpected changes in the oxic/anoxic interface in the Black Sea: Nature, v. 338, p. 411-413, doi:10.1038/338411a0.

Murray, J.W., Codispoti, L.A., and Friederich, G.E., 1995, Oxidation-reduction environments: The suboxic zone in the Black Sea, in Huang, C.P., et al., eds., Aquatic chemistry: Interfacial and interspecies processes: Advances in Chemistry Series No. 244, p. 157-176.

Nägler, T.F., Siebert, C., Luschen, H., and Böttcher, M.E., 2005, Sedimentary Mo isotope record across the Holocene fresh-brackish water transition of the Black Sea: Chemical Geology, v. 219 , p. $283-295$, doi:10.1016/j.chemgeo .2005 .03 .006

Nägler, T.F., Neubert, N., Böttcher, M.E., Dellwig, O., and Schnetger, B., 2011, Molybdenum isotope fractionation in pelagic euxinia: Evidence from the modern Black and Baltic Seas: Chemical Geology, v. 289, p. 1-11, doi:10.1016/j .chemgeo.2011.07.001

Neretin, L.N., Volkov, I.I., Böttcher, M.E., and Grinenko, V.A., 2001, A sulfur budget for the Black Sea anoxic zone: Deep-Sea Research Part I: Oceanographic Research Papers, v. 48, p. 2569 2593, doi:10.1016/S0967-0637(01)00030-9.

Neubert, N., Nägler, T.F., and Böttcher, M.E., 2008, Sulfidity controls molybdenum isotope fractionation into euxinic sediments: Evidence from the modern Black Sea: Geology, v. 36, p. 775-778, doi:10.1130/G24959A.1.

Pearce, C.R., Cohen, A.S., Coe, A.L., and Burton, K.W., 2008, Molybdenum isotope evidence for global ocean anoxia coupled with perturbations to the carbon cycle during the Early Jurassic: Geology, v. 36, p. 231-234, doi:10.1130 /G24446A.1.

Repeta, D.J., 1993, A high-resolution historical record of Holocene anoxygenic primary production in the Black Sea: Geochimica et Cosmochimica Acta, v. 57, p. 4337-4342, doi:10.1016 /0016-7037(93)90334-S.

Severmann, S., Lyons, T.W., Anbar, A., McManus, J., and Gordon, G., 2008, Modern iron isotope perspective on the benthic iron shuttle and the redox evolution of ancient oceans: Geology, v. 36, p. 487-490, doi:10.1130/G24670A.1.

Siebert, C., Nägler, T.F., von Blanckenburg, F., and Kramers, J.D., 2003, Molybdenum isotope records as a potential new proxy for paleoceanography: Earth and Planetary Science Letters, v. 211 , p. $159-171$, doi: $10.1016 /$ S0012 $-821 \mathrm{X}(03) 00189-4$

Tossell, J.A., 2005, Calculating the partitioning of the isotopes of Mo between oxidic and sulfidic species in aqueous solution: Geochimica et Cosmochimica Acta, v. 69, p. 2981-2993, doi:10.1016/j.gca.2005.01.016.

Wille, M., Kramers, J.D., Nägler, T.F., Beukes, N.J., Schröder, S., Meisel, T., Lacassie, J.P., and Voegelin, A.R., 2007, Evidence for a gradual rise of oxygen between 2.6 and $2.5 \mathrm{Ga}$ from Mo isotopes and Re-PGE signatures in shales: Geochimica et Cosmochimica Acta, v. 71, p. 2417-2435, doi:10.1016/j.gca.2007.02.019.

Manuscript received 17 October 2011

Revised manuscript received 25 January 2012

Manuscript accepted 2 February 2012

Printed in USA 